\title{
COMMENTS
}

\section{Asserting In Personam Jurisdiction over Foreign Cybersquatters}

\author{
Jason W. Callen†
}

Imagine Mr. Blofeld, a foreign entrepreneur, who discovered the perfect way to make a fast buck. ${ }^{1}$ He registered the Internet domain name "pentium3.com" with Verisign, a domain registry based in Virginia, and then set up a pornographic website at that address. Around the world, Internet users seeking information on Intel, the manufacturer of the Pentium computer processor, were diverted to Blofeld's site. Blofeld could either continue to profit from the Internet traffic intended for the Intel website or offer to sell advertising space on his webpage to Intel's competitors. Even though these activities confused consumers and tarnished the value of Intel's protected mark, Intel could do little to stop him. Blofeld had not directly attempted to extort money from Intel. Since Blofeld's only contact in the United States was the registration of the domain name with the Virginia registry, he seems beyond the jurisdictional reach of United States courts.

This hypothetical case of cyberpiracy is typical of a problem known as "cybersquatting." Cybersquatting consists of registering, trafficking in, or using Internet addresses that are identical or confusingly similar to protected trademarks. ${ }^{2}$ Cybersqatters often register these famous marks as domain names in order to profit from the mark's goodwill or for the purpose of disparaging the mark. They pi-

\footnotetext{
† B.A. 1998, Washington and Lee University; J.D. Candidate 2003, The University of Chicago.

1 These facts are loosely based on an incident described in a Senate Report discussing the problem of cybersquatting. The Anticybersquatting Consumer Protection Act, S Rep No 106-140, 106th Cong, 1st Sess 6 (1999).

2 See Trademark Cyberpiracy Prevention Act, HR Rep No 106-412, 106th Cong, 1st Sess 8 (1999).

3 See id. Cybersquatters register distinctive marks for various reasons. Anticybersquatting Act, S Rep No 106-140 at 5-7 (cited in note 1). Some do so in order to extort payment from the trademark owner, while others register the marks with the hope of selling them to the highest bidder. See id. Many, however, have motives similar to those of the hypothetical cybersquatter,
} 
rate the marks of companies ranging from McDonald's to Warner Brothers. ${ }^{4}$ Some are foreign nationals like Blofeld who have no contacts in the United States beyond domain registration.'

Because cybersquatters often live abroad, an owner of a mark may have trouble haling someone like Blofeld into a United States federal court. Most courts hold that domain registration itself does not establish sufficient contacts with the forum state because most registrants are unaware of, and potentially unable to discover, where their domain name is registered. ${ }^{6}$ Since a court may only exercise in personam jurisdiction " over a defendant when that individual has such "minimum contacts" with the forum state, courts are unable to assert in personam jurisdiction over these individuals.

Congress sought to remedy this situation through the Anticybersquatting Consumer Protection Act (ACPA). ${ }^{9}$ The Act grants mark owners the right to file in rem actions ${ }^{10}$ against the domain name in the forum in which the registrar is located so long as the mark owners

Blofeld, mentioned above. They may benefit from the mark's goodwill because the website may derive advertising revenue from the number of times it is accessed. See id at 6 . Cybersquatters may also register famous marks in order to engage in unfair competition and prey on consumer confusion. See id. A typical example of this is a cybersquatter who operated a website under the domain name "disneytransportation.com". See id. The business offered shuttle services in the Orlando area and reservations at Disney hotels, although the company was in no way affiliated with the Walt Disney Company and this fact was not indicated on the website. See id.

4 See Anticybersquatting Act, S Rep No 106-140 at 5-6 (cited in note 1).

5 See Intellectual Property and Communications Omnibus Reform Act of 1999, HR Conf Rep No 106-464, 106th Cong, 1st Sess 114 (1999) ("In an effort to avoid being held accountable for their infringement or dilution of famous trademarks, cyberpirates often . . . have used offshore addresses or companies to register domain names.").

6 See, for example, Cable News Network LP, LLLP v CNNews.com, 162 F Supp 2d 484, 489 n 16 (E D Va 2001) ("It is sensibly settled that these contacts do not provide a constitutionally adequate basis for the exercise of in personam jurisdiction.") (citation omitted); America Online, Inc v Huang, 106 F Supp 2d 848, 856 (E D Va 2000) (holding that entrance into domain name registration agreements with a Virginia registrar does not amount to minimum contacts with Virginia for purposes of exercising personal jurisdiction); Banco Inverlat, SA v Inverlat.com, 112 F Supp 2d 521, 522 n 1 (E D Va 2000) (finding that mere registration of a disputed domain name with Network Solutions, Inc. (NSI) in Virginia is insufficient to subject a defendant to personal jurisdiction); Heathmount AE Corp v Technodome.com, 106 F Supp 2d 860, 866 (E D Va 2000) (emphasizing that because defendants do not purposefully avail themselves of the forum through mere registration, personal jurisdiction is lacking).

7 In personam jurisdiction, often referred to as personal jurisdiction, describes the power of a court to bring persons into its adjudicative process. See Black's Law Dictionary 857 (West 7 th ed 1999).

8 See International Shoe Co v Washington, 326 US 310, 316 (1945) (establishing that courts may exercise personal jurisdiction when the defendants have "minimum contacts" with the forum state such that exercise of jurisdiction comports with "traditional notions of fair play and substantial justice").

9 Pub L No 106-113, 113 Stat 1536 (1999), codified at 15 USC $\$ 1125$ (d) (2000) (enacted as Title III of the Intellectual Property and Communications Omnibus Reform Act of 1999).

10 In rem jurisdiction describes the power of a court to adjudicate the rights to a given piece of property, including the power to seize and hold it. See Black's Law Dictionary 856 (West 7th ed 1999). 
show that a cybersquatter lacks minimum contacts and is not subject to in personam jurisdiction. "Because some courts hold that the minimum contacts standard does not apply to in rem claims filed in the forum state in which the property is located, plaintiffs can use the ACPA to obtain relief when the court would otherwise lack in personam jurisdiction over the property owner. ${ }^{12}$

The exercise of in rem jurisdiction over domain names owned by foreign defendants, however, presents constitutional problems. In Shaffer $v$ Heitner, ${ }^{13}$ the Supreme Court suggested that all exercises of jurisdiction must satisfy the minimum contacts standard. ${ }^{14}$ Shaffer indicates that plaintiffs filing in rem actions must still show that property owners have established minimum contacts with the forum state. Shaffer's holding raises doubts as to the validity of the ACPA insofar as it bars plaintiffs from bringing in rem actions if minimum contacts exist. Unable to file in rem claims, mark owners may pursue in personam actions against the cybersquatter. Plaintiffs, however, will face difficulties when the defendant's only contact with the forum state is registration. The mechanics of the registration process demonstrate that registrants do not "purposefully avail" themselves of the benefits of the forum state, as required by the Court's in personam jurisdiction holdings. ${ }^{15}$

This Comment argues that mark owners may obtain in personam jurisdiction over foreign cybersquatters through the "effects" doctrine and Federal Rule of Civil Procedure 4(k)(2). The Supreme Court first announced the "effects" doctrine in Calder $v$ Jones. ${ }^{16}$ The doctrine states that courts may constitutionally exercise in personam jurisdiction when defendants intentionally cause harm within the forum. This doctrine may be combined with Rule 4(k)(2), which allows federal courts to aggregate contacts over the entire country when considering whether the court has jurisdiction, in order to hear a cybersquatting case. When cybersquatters, like Blofeld, register trademark-infringing

11 See 15 USC \$ 1125(d)(2).

12 See, for example, Cable News Network, 162 F Supp 2d at 491-92 (holding that in an ACPA in rem action it is not necessary that the allegedly infringing registrant have minimum contacts with the forum so long as the registry is located there).

13433 US 186 (1977).

14 See id at 212 ("[A]ll assertions of state court jurisdiction must be evaluated according to the standards set forth in International Shoe and its progeny.").

15 See Part II.C.

16465 US 783 (1984) (finding personal jurisdiction proper when the defendant expressly aimed tortious conduct at the forum state although he himself was not actually present in the forum).

17 Fed R Civ P 4(k)(2) specifically provides:

If the exercise of jurisdiction is consistent with the Constitution and laws of the United States, serving a summons or filing a waiver of service is also effective, with respect to claims arising under federal law, to establish personal jurisdiction over the person of any 
domain names and engage in activities that tarnish the value of the mark, they intentionally injure mark owners in the United States. Cybersquatters establish minimum contacts with the nation as a whole because mark owners suffer harm in the United States. Based on these nationwide contacts, federal courts may exercise in personam jurisdiction under Rule 4(k)(2).

This Comment is divided into three parts. Part I discusses the mechanics of domain name registration, how the ACPA operates, and the Supreme Court's jurisprudence on in personam and in rem jurisdiction. Part II illustrates why the ACPA's in rem provision is of questionable value to plaintiffs. It begins with an examination of the division among courts over whether mark owners filing in rem claims under the Act must also establish that the domain owner has minimum contacts with the forum. It concludes by demonstrating why ACPA claims must satisfy the minimum contacts test and why mere registration is insufficient to establish such contacts with the forum state. Finally, Part III illustrates how mark owners may achieve greater success using the "effects" doctrine and Rule $4(\mathrm{k})(2)$ to file in personam claims against foreign cybersquatters.

\section{THE ACPA AND IN REM AND IN PERSONAM JURISDICTION}

The growth of the Internet has led to an increase in the value of trademarks. ${ }^{18}$ Businesses use their marks as domain names to attract consumers to their websites. The increase in value and usage of protected marks on the Internet has led to a corresponding increase in cybersquatting. ${ }^{19}$ Congress responded by providing mark owners with a civil remedy through the ACPA. The ability of mark owners to obtain the relief provided by the ACPA depends, however, on whether a court may assert in personam jurisdiction over the cybersquatter or in rem jurisdiction over the offending domain name.

defendant who is not subject to the jurisdiction of the courts of general jurisdiction of any state.

18 See Part I.A. See generally, HR Rep 106-412 at 5 (cited in note 2); Panavision International, LP v Toeppen, 945 F Supp 1296, 1299 (C D Cal 1996), affd, 141 F3d 1316 (9th Cir 1998) (noting that Internet consumers frequently search for businesses' websites under their trademarks).

19 See generally, HR Rep 106-412 at 5-6 (cited in note 2); Paul Farhi, $A$ Web 'Squatter' Beats Exxon Mobil to Its Site, Wash Post E1 (Dec 3, 1998).

20 See Part I.C. 


\section{A. The Internet and Domain Names}

Businesses maintain Internet websites to provide information, products, and services to consumers and other businesses. ${ }^{21}$ These companies increase their visibility by registering unique domain names to identify their websites. ${ }^{2}$ In order to connect with Internet users, businesses frequently register their trademarks as domain names. ${ }^{23}$ For example, a consumer interested in Nike shoes may easily guess that Nike's website address is "nike.com." If a user cannot guess the domain name, however, the user must search for the site using an Internet search engine, such as Google, to search for keywords likely to appear on the website. ${ }^{24}$ Since these searches often yield thousands of matches, users may experience difficulty finding the website. ${ }^{25}$ Businesses thus have a strong interest in using personalized, easily identifiable marks as domain names.

Between 1992 and 1998, Network Solutions, Inc. (NSI), a Virginia-based company, served as the exclusive registrar and registry for the domain name system. ${ }^{27}$ Registration occurred online, took only a matter of minutes, and took place on a first-come, first-served basis. Registrants needed only to provide the name or organization using

21 See Panavision International, LP v Toeppen, 945 F Supp 1296, 1299 (C D Cal 1996), affd, 141 F3d 1316 (9th Cir 1998) ("[B]usinesses have begun to use the Internet to provide information and products to consumers and other businesses.").

22 Every website has a unique numerical address, referred to as an Internet Protocol (IP) address. See id. Each IP address, which is often long and difficult to remember, corresponds to a more user-friendly alphanumeric address known as a domain name. See Thomas R. Lee, In Rem Jurisdiction in Cyberspace, 75 Wash L Rev 97, 100 (2000). Domain names are the familiar ".com" and ".edu" addresses commonly seen on the Internet. See Panavision, 945 F Supp at 1299 (noting that ".com" is commonly used by commercial entities and ".edu" by educational entities). They identify the entity maintaining the website and enable users to locate websites more quickly and easily. See id.

23 See Panavision, 945 F Supp at 1299 ("Because users ... may not be able to access websites at all when they do not know (or cannot deduce) the proper domain name, businesses frequently register their names and trademarks as domain names.").

24 See id (discussing search engines). See also <http://www.google.com> (visited Oct 5 , 2002).

25 See Panavision, 945 F Supp at 1299 (noting that a key word search frequently yields thousands of websites).

26 See id (noting that businesses frequently use known or deducible domain names to facilitate consumers' ability to locate their web pages).

27 See National Telecommunications and Information Administration, Management of Internet Names and Addresses, 63 Fed Reg 31, 741-42 (1998). The functions of a registry are distinct from that of a registrar. See Cable News Network LP, LLLP y CNNews.com, $162 \mathrm{~F}$ Supp $2 \mathrm{~d}$ $484,486 \mathrm{n} 4$ (E D Va 2001) (distinguishing a registrar from a registry). A registrar is simply one of several entities authorized to grant registrations of domain names. See id. A registry, however, is the only entity that maintains all official records regarding registrations in a top level domain such as ".com" or ".edu". See id.

28 See Lee, 75 Wash L Rev at 102-03 (cited in note 22) ("The process of registering a domain name through NSI is inexpensive, potentially anonymous and virtually instantaneous and that NSI distributes domain name registrations on a first-come, first-served basis."). 
the domain name and contact information. ${ }^{29}$ NSI charged a small, annual fee to maintain the domain name in its directory and link the domain name with its corresponding IP address. ${ }^{30}$ NSI did not screen domain name applications to determine if individuals were registering protected marks as domain names.

Today, users may register with any number of registrars over the Internet. ${ }^{32}$ The method of registration described above, however, remains unchanged. ${ }^{33}$ NSI, recently acquired by Verisign Global Registry Services, continues to serve as the largest registrar and registry for domain names registered by American businesses. ${ }^{34}$

\section{B. The ACPA}

The ACPA provides mark owners with a remedy against the type of trademark piracy described above. ${ }^{35}$ The Act holds liable individuals who act in bad faith in registering or trafficking in domain names that are "identical or confusingly similar" to protected marks. Mark owners proceeding in personam against cybersquatters may seek both legal and equitable remedies."

In enacting the ACPA, Congress recognized that many foreign cybersquatters do not have minimum contacts with any one state and were thus successfully able to avoid the reach of United States courts on jurisdictional grounds. ${ }^{38}$ To account for cybersquatters like Blofeld, over whom the court may not exercise in personam jurisdiction, the ACPA includes an in rem provision that allows mark owners to file

29 See id at $102-03$.

30 See America Online, Inc v Huang, 106 F Supp 2d 848, 850 (E D Va 2000) (noting that domain names can now be secured from a registry for $\$ 35$ per year or less); Ariana E. Cha, Seven New Domain Suffixes Approved; Expanded List Widens Online Possibilities, Wash Post E1 (Nov 17,2000) (same).

31 See America Online, $106 \mathrm{~F}$ Supp $2 \mathrm{~d}$ at 853.

32 For a list of registrars from around the world, see ICANN-Accredited Registrars, available at <http://www.icann.org/registrars/accredited-list.html> (visited May 16, 2002).

33 See, for example, Network Solutions, available online at <http://wwwnetsol.com> (visited May 16, 2002); Alldomains.com, available online at $<\mathrm{http}: / \mathrm{www}$. alldomains.com $>$ (visited May 16,2002).

34 See About Verisign, available online at <http://corporate.verisign.com/news/fact.html> (visited May 16, 2002). Verisign serves as the exclusive registry for the ".com" domains. See id.

35 See ACPA $\S 3002,113$ Stat at 1536.

3615 USC $\$ 1125$ (d)(1)(A). Courts may consider a variety of factors in determining whether a defendant has acted in bad faith, including whether the registrant attempted to extort payment from the mark owner or intended to divert consumers from the mark owner's online location to his own web page. See 15 USC $\$ 1125(d)(1)(B)$.

37 See 15 USC $\$ 1125$ (d)(1)(C)-(D).

38 Congress drafted the ACPA's in rem provision with two types of defendants in mind: individuals who preserved their anonymity by providing false contact information to the registrar, and foreigners with few contacts in the United States. See HR Rep No 106-412 at 14 (cited in note 2). This Comment focuses on the ability of courts to obtain jurisdiction over the latter group of defendants. 
claims directly against the infringing domain names in the judicial district in which the domain name registry, registrar, or domain name authority is located. ${ }^{39}$ Before filing such claims, however, owners must show either that defendants are not subject to in personam jurisdiction ${ }^{4 t}$ or that they cannot identify the proper defendants. ${ }^{41}$ Relief under the in rem provision is also limited to cancellation of the domain name or transfer to the plaintiff.

\section{General Jurisprudence on In Personam and In Rem Jurisdiction}

The ability of mark owners to obtain relief under the ACPA depends on whether courts may assert in personam jurisdiction over the cybersquatters or in rem jurisdiction over the offending domain names. In a series of decisions since 1945, the Supreme Court has dictated the constitutional requirements for the exercise of jurisdiction.

1. Territorialism and the distinction between in personam and in rem jurisdiction.

Through the first half of the twentieth century, the principles of territoriality articulated in Pennoyer $v$ Neff $^{43}$ defined jurisdictional boundaries. Throughout this period, courts could exercise jurisdiction only over persons and property located within their own territory. ${ }^{4}$ Three types of judicial action emerged from Pennoyer. Courts can exercise: (1) in personam jurisdiction over an individual in an action determining the "rights and obligations of the defendant;" (2) in rem, or "true" in rem, jurisdiction over property in a proceeding to determine the rights of all to the property; and (3) quasi in rem jurisdiction over property in an action to determine the rights of specified claimants to a thing. In rem actions may be further distinguished from quasi in rem actions. In rem actions involve claims between parties to property located in the forum state and on which the jurisdiction of the court is based. ${ }^{45}$ Quasi in rem claims differ in that the property does not give

39 See 15 USC \$ 1125 (d)(2).

40 See 15 USC $\$ 1125(d)(2)(A)(i i)(I)$.

41 See 15 USC \$ 1125(d)(2)(A)(ii)(II).

42 See 15 USC $\$ 1125$ (d)(2)(D).

4395 US 714 (1877) (holding that no state may exercise direct jurisdiction and authority over property outside of its territory).

44 See id at 722 (noting that each state's laws have "no operation outside its territory except so far as is allowed by comity").

45 See id at 727; Linda J. Silberman, Shaffer v. Heitner: The End of an Era, 53 NYU L Rev 33,39 (1978) (stating that the Pennoyer Court identified three categories of jurisdiction).

46 See Jack H. Friedenthal, Mary Kay Kane, and Arthur R. Miller, Civil Procedure 98 (West 3d ed 1999); Fleming James, Jr., Geoffrey C. Hazard, Jr., and John Leubsdorf, Civil Procedure 2224 (Foundation 4th ed 1992). 
rise to the underlying cause of action. The plaintiff's claim, possibly in tort or contract, is unrelated to the property located in the forum state. ${ }^{48}$ The court attaches this property, however, as a basis for exercising jurisdiction over a defendant who otherwise would not be subject to in personam jurisdiction for the plaintiff's claim. ${ }^{49}$ Actions under the in rem provision of the ACPA are typically characterized as true in rem actions because the mark owner's claim is based on his purported right to the domain address "housed" in the forum.

\section{The exercise of in personam jurisdiction after} International Shoe.

In personam jurisdictional analysis shifted dramatically with the Supreme Court's ruling in International Shoe $v$ Washington. ${ }^{\text {st }}$ Under International Shoe, courts can assert jurisdiction over defendants if: (1) defendants have minimum contacts with the forum state; and (2) the exercise of jurisdiction is reasonable, comporting with "traditional notions of fair play and substantial justice.",52

Minimum contacts and reasonableness now dictate the jurisdictional reach of courts. An individual establishes minimum contacts when he "purposefully avails" himself of the privilege of conducting activities within the forum, thus invoking the "benefits and protections of its laws." ${ }^{53}$ Defendants' connection with the forum must be such that

47 See James Wm. Moore, Moore's Federal Practice, § 108.70[2] at 107 (3d ed 2002) (stating that type II quasi in rem actions occur when the plaintiff asserts another claim against the defendant and seeks to establish an interest in the defendant's property as a basis for exercising jurisdiction). Quasi in rem jurisdiction is often divided into two categories, type I and type II. See id at 106-08. Type I quasi in rem actions, like in rem actions, involve claims between parties to property that serve as the basis for jurisdiction. See James, Hazard, and Leubsdorf, Civil Procedure at 66 (cited in note 46); Silberman, 53 NYU L Rev at 39 (cited in note 45). Type II quasi in rem actions concern a claim that does not relate to the property. Through attachment, property owned by the defendant is seized at the beginning of the action and held with a view of giving it to the plaintiff if the claim against the defendant is sustained on the merits. See James, Hazard, and Leubsdorf, Civil Procedure at 66 (cited in note 46). In practice, there is no real difference between a true in rem action and a type I quasi in rem action. See Lee, In Rem Jurisdiction in Cyberspace, 75 Wash L Rev at 112 (cited in note 22) (noting that the Restatement (Second) of Conflict of Laws abandons entirely the distinction between the two). For the purposes of this Comment, I will thus treat quasi in rem actions as possessing the characteristics of type II quasi in rem claims and will consider type I quasi in rem and true in rem actions to be the same.

48 See Moore, Moore's Federal Practice, \$108.70[2] at 107 (cited in note 47).

49 See id.

50 See generally Cable News Network LP, LLLP v CNNews.com, 162 F Supp 2d 484, 490 (E D Va 2001) ("ACPA in rem actions ... are of the 'true in rem' genre because they involve the rights of a disputed mark for every potential rights holder."). Theoretically, in rem claims filed under the ACPA may also be characterized as type I quasi in rem actions since there is no practical difference between the two types of jurisdiction. See note 47 .

51326 US 310 (1945).

52 Id at 316 (quotations omitted).

53 Hanson v Denckla, 357 US 235, 253 (1958). 
they should "reasonably anticipate being haled into court" in that state.

In assessing reasonableness, courts engage in a balancing test and consider a variety of factors including: (1) the interests of the forum state; (2) the plaintiff's interests in obtaining relief; and (3) the burdens placed on the defendant. ${ }^{\text {ss }}$ Courts may presume that an exercise of jurisdiction is reasonable when defendants purposefully direct their activities at forum residents. In such cases, defendants have the burden of proof and must present a "compelling case" that jurisdiction is unreasonable. The reasonableness prong of International Shoe takes on greater significance when plaintiffs face overseas defendants like foreign cybersquatters. In Asahi Metal Industry Co, Ltd v Superior Court of California, the Supreme Court dismissed an indemnity action in California between a Japanese corporation and a Taiwanese manufacturer. The Court found that the exercise of jurisdiction over the claim was unreasonable since the heavy burdens placed on the Taiwanese defendant in travel expenses outweighed any interest California or the Japanese business had in litigating in California. ${ }^{59}$

\section{In rem jurisdiction after International Shoe.}

The scope of the International Shoe standard is not limited to exercises of in personam jurisdiction. In Shaffer, the Supreme Court suggested that minimum contacts rules apply to all assertions of jurisdiction." Shaffer involved a Delaware state court's exercise of quasi in rem jurisdiction in a shareholder derivative suit against a group of nonresident defendants. ${ }^{61}$ The state court could not assert in personam jurisdiction over the defendants since they lacked minimum contacts with Delaware. ${ }^{62}$ Instead, the court exercised quasi in rem jurisdiction

54 World-Wide Volkswagen Corp v Woodson, 444 US 286, 297 (1980).

5s See Asahi Metal Industry Co, Ltd v Superior Court of California, 480 US 102, 113 (1987). Other factors are "the interstate judicial system's interest in obtaining the most efficient resolution of controversies; and the shared interest of the several States in furthering fundamental substantive social politics." Id, quoting World-Wide Volkswagen, 444 US at 292.

56 Burger King Corp v Rudzewicz, 471 US 462, 477 (1984) ("Where a defendant who purposefully has directed his activities at forum residents seeks to defeat jurisdiction, he must present a compelling case that the presence of some other considerations would render jurisdiction unreasonable.").

57480 US 102 (1987).

58 Id at $105-06,108$.

59 See id at 114 (noting also the "unique burdens placed on one who must defend oneself in a foreign legal system").

60 See 433 US at 212.

61 See id at 193 (noting that the Delaware court stated that the primary purpose of the sequestration was "to compel the personal appearance of a nonresident defendant").

62 See id at 213 (recognizing that the plaintiff "did not allege and does not now claim that [defendants] have ever set foot in Delaware"). 
over the nonresident defendants by the sequestering of the defendants' stock in a Delaware corporation. ${ }^{63}$

The Supreme Court ruled that the Delaware court could exercise jurisdiction only if the defendants had minimum contacts with the forum. ${ }^{64}$ In broad terms, the Court held that "all assertions of state-court jurisdiction must be evaluated according to the standards set forth in International Shoe and its progeny." ${ }^{\text {"S }}$ The Court found that the exercise of jurisdiction over property was in fact an assertion of jurisdiction over the owner of the property and must be judged under the minimum contacts standard. ${ }^{6}$ In dicta, the Court suggested that it intended its holding to apply to quasi in rem claims and also to "true" in rem actions, such as those filed under the ACPA, in which the action arises from direct claims to property located in the forum. ${ }^{67}$ The Court analyzed the impact of the minimum contacts test on in rem claims and noted that in these cases, "the presence of property in a state may bear on the existence of jurisdiction by providing contacts among the forum State, the defendant, and the litigation."

\section{The "effects" doctrine and minimum contacts.}

The Supreme Court has expanded the ways in which defendants may establish minimum contacts sufficient for the exercise of in personam jurisdiction. ${ }^{69}$ Defendants who aim tortious conduct at forum residents may establish minimum contacts. ${ }^{\text {Th }}$ In Calder, for example, the Supreme Court held that a Florida reporter and his editor could be subject to jurisdiction in California after the reporter wrote an allegedly libelous story attacking a California resident. ${ }^{\text {"1 }}$ Even though the defendants authored and edited the story in Florida, the Court found California to be the focal point of both the story and the harm

63 See id at 194 (stating that the Delaware court held that "the statutory Delaware situs of the stock provided a sufficient basis for the exercise of quasi in rem jurisdiction by a Delaware court").

64 Id at 216-17.

65 Id at 212.

66 See id ("The fiction that an assertion of jurisdiction over property is anything but an assertion of jurisdiction over the owner of the property supports an ancient form without substantial modern justification.").

67 See id at 207 ("The standard for determining whether an exercise of jurisdiction over the interests of persons is consistent with the Due Process Clause is the minimum-contacts standard elucidated in International Shoe.").

68 Id.

69 See, for example, Calder v Jones, 465 US 783, 791 (1984) (finding that a Florida defendant possessed sufficient contacts with California because conduct consisted of "intentional conduct in Florida calculated to cause injury to respondent in California").

70 See id at 789-90.

71 Id at 788. 
suffered. " Under Calder's "effects" test, a defendant who has never entered the forum state can nevertheless be subject to jurisdiction if the defendant: (1) commits an intentional act expressly aimed at the forum; and (2) that act causes harm that (a) is felt primarily in the forum and (b) the defendant knew would be felt in the forum.

Courts have employed the "effects" doctrine to assert in personam jurisdiction over cybersquatters engaged in extortion. ${ }^{\text {p }}$ In Panavision International, LP $v$ Toeppen, ${ }^{\text {is }}$ a case decided before the enactment of the ACPA, the plaintiff filed claims against the cybersquatter under the Federal Trademark Dilution Act of $1995 .^{76}$ This provision, unlike the ACPA, does not hold individuals liable for the mere registration of marks that are identical or confusingly similar to protected marks. ${ }^{n}$ In Panavision, the Ninth Circuit held that an Illinois defendant established minimum contacts with the forum state after registering a California company's trademark and then attempting to extort money from that business in California. ${ }^{73}$ The defendant established minimum contacts because he sent demands for payment to Panavision in California and he was aware that his conduct would have the effect of injuring that business in the forum state. ${ }^{79}$ In $\mathrm{Mac}-$ Connell v Schwamm, a federal district court similarly held that a cybersquatter residing in Japan established minimum contacts in California after attempting to extort money from a California business. The court found jurisdiction proper under Panavision because the defendant had sent emails demanding payment to the mark owner in California. ${ }^{.2}$ No court has applied the effects doctrine to assert in personam jurisdiction over a cybersquatter, such as Blofeld, who registers

72 See id at 789 (noting that the plaintiff suffered the brunt of the harm, both in terms of her emotional distress and injury to her professional reputation, in California).

73 See id (holding that since California was the focal point of the harm suffered, jurisdiction was "proper in California based on the 'effects' of [the defendants' intentional] Florida conduct in California").

74 See Panavision International, LP v Toeppen, 141 F3d 1316, 1322 (9th Cir 1998) (holding an Illinois defendant subject to in personam jurisdiction in California under the "effects test" when he registered a California plaintiff's trademark as a domain name and attempted to extort money from the plaintiff); MacConnell $v$ Schwamm, 2000 US Dist LEXIS 13850, *9-13 (S D Cal 2000) (holding that jurisdiction may be exercised over a defendant where registration of a domain name amounts to tortious conduct aimed at forum residents as part of a scheme to extort money).

$75 \quad 141 \mathrm{~F} 3 \mathrm{~d} 1316$.

7615 USC \$1125(c). Panavision, $141 \mathrm{FBd}$ at 1319.

77 See 15 USC $\$ 1125$ (c).

78 See $141 \mathrm{~F} 3 \mathrm{~d}$ at 1322.

79 See id at 1319,1322

802000 US Dist LEXIS 12850 (S D Cal 2000).

81 See MacConnell, 2000 US Dist LEXIS 13850 at $* 10$. The defendant did not, however, claim to be a citizen of Japan. Id at *18. He also allegedly had substantial contacts with California, where he owned property, paid taxes, and maintained a mailing address. Id at *7.

82 Id at $* 3-4, * 11-12$. 
a protected mark with a bad faith intent to profit from or disparage the mark but who does not attempt to extort the mark owner. ${ }^{33}$

\section{Rule 4(k)(2) and minimum contacts.}

Federal courts may exercise in personam jurisdiction over foreign defendants based on their contacts with the nation as a whole if the underlying statute authorizes nationwide service of process. ${ }^{84}$ Even if the federal statute does not authorize nationwide service, federal courts may assert personal jurisdiction over foreign defendants who have ample contacts with the nation as a whole, but whose contacts are so scattered that no one state could exercise personal jurisdiction.

83 Panavision and MacConnell both suggest that plaintiffs may not establish in personam jurisdiction over a cybersquatter by pointing solely to the defendant's registration of a trademark-infringing domain name. See Panavision, 141 F3d at 1322; MacConnell, 2000 US Dist LEXIS 13850 at $* 10$. The Ninth Circuit argued that "something more" was needed to demonstrate that the defendant directed his activity toward the forum and sought to harm the mark owner. Panavision, 141 F3d at 1322. Each court found this requirement satisfied based on the defendant's intent to harm the mark owner through an extortionist scheme. A plaintiff should also, however, be able to fulfill this requirement by simply showing that the cybersquatter acted with the bad faith intent to harm the mark owner. Cybersquatters who register domain names with the intent of diverting customers to their sites or for the purposes of disparaging the mark similarly seek to harm the mark owner in the forum. When viewed in this light, the requirement of "something more" may be seen as an attempt by the Ninth Circuit to require that plaintiffs demonstrate that the defendants did not register the domain name in good faith for legitimate business reasons. Neither of these courts directly examined the provisions of the ACPA-Panavision was decided two years before passage of the Act and MacConnell simply applied Panavision's holding. If these courts had examined the ACPA, they would have noted that the Act contains a similar requirement. Plaintiffs filing in personam claims under the ACPA already must demonstrate that the registrant acted with bad faith intent. 15 USC $\$ 1125$ (d)(1)(A).

84 See Sheet Metal Workers' National Pension Fund v Elite Erectors, Inc, 212 F3d 1031, 1035-36 (7th $\mathrm{Cir} 2000$ ) (stating that nationwide service under federal statutes is proper as long as defendants have adequate contacts with the United States as a whole); United Rope Distributors, Inc $v$ Seatriumph Marine Corp, 930 F2d 532, 534 (7th Cir 1991) ("When a national court applies national law, the due process clause requires only that the defendant possess sufficient contacts with the United States."). But see Peay v Bell South Medical Assistance Plan, 205 F3d 1206 (10th Cir 2000) (examining defendant's contacts with the forum state in a suit when the statute provided for nationwide service of process). The Supreme Court has yet to rule expressly on the sufficiency of nationwide contacts as a basis for jurisdiction. See Omni Capital International v Rudolf Wolff \& Company, 484 US 97, 102-03 n 5 (1987) (noting that the issue of whether the Due Process clause of the Fifth Amendment would be satisfied by aggregating nationwide contacts was not before the Court). Nevertheless, in Republic of Argentina v Weltover, Inc, 504 US 607 (1992), the Court seemed to endorse a "national contacts" test when it held that the defendant was subject to personal jurisdiction since it had "purposefully availed itself of the privilege of conducting activities within the United States." Id at 620 (quotation omitted). It has been argued, however, that this ruling does not amount to an endorsement since jurisdiction was asserted in a federal district where the defendant clearly had contacts. See Leslie M. Kelleher, The December 1993 Amendments to the Federal Rules of Civil Procedure-A Critical Analysis, 12 Touro L Rev 7, 49 (1995) (observing that the Republic of Argentina had contacts in New York sufficient to establish jurisdiction in the district court there without regard to nationwide contacts).

85 See, for example, ISI International, Inc v Borden Ladner Gervais LLP, 256 F3d 548, 551 (7th $\mathrm{Cir} 2001$ ) (exercising jurisdiction over a foreign defendant under Rule $4(\mathrm{k})(2)$ based on the fact the defendant sent letters to California, engaged a law firm in Michigan, and filed for a pat- 
These courts rely on FRCP 4(k)(2), which grants federal courts the statutory authority to exercise in personam jurisdiction when: (1) a federal claim is asserted; (2) the defendant has contacts with the nation as a whole; and (3) the defendant is not subject to personal jurisdiction in any particular state. ${ }^{86}$

Rule 4(k)(2) was intended to fill in a gap in the enforcement of federal laws. Prior to the rule's enactment, when a claim arose under a federal statute that did not provide a mechanism for nationwide service of process, ${ }^{57}$ the district court could only assert in personam jurisdiction if the defendant had established minimum contacts with the state in which the court sat. ${ }^{\mathrm{s}}$ Foreign defendants often evaded federal jurisdiction since they lacked sufficient contacts with any one state. ${ }^{89}$ Courts now use Rule $4(\mathrm{k})(2)$ to enforce claims arising under federal statutes that do not contain nationwide service of process provisions. Since the ACPA lacks a service provision for in personam claims, plaintiffs may rely on Rule $4(\mathrm{k})(2)$ as a statutory source of jurisdiction. The rule enables mark owners to assert in personam claims against foreign cybersquatters who, while lacking minimum contacts with any one state, have sufficient contacts with the nation as a whole.

In summary, businesses register their protected marks as domain names in order to attract consumers. The ACPA grants these owners the right to file in personam actions against cybersquatters or in rem claims against domain names that infringe on trademarks. Courts may assert in personam jurisdiction over cybersquatters if they have minimum contacts with the forum and if this exercise of jurisdiction is reasonable. Shaffer also may require that mark owners seeking to establish in rem jurisdiction over infringing domain names demonstrate that the domain owner has minimum contacts with the forum. Plain-

ent in the United States).

86 See United States v Swiss American Bank, 191 F3d 30 (1st Cir 1999).

87 See, for example, Commodity Exchange Act, 42 Stat 988, as amended, 7 USC $\$ 1$, et seq (1982 \& Supp IV), cited in Omni Capital, 484 US at 100.

83 See Swiss American, 191 F3d at 36 ("A court need not even consider [constitutional problems] unless it possess statutory authorization to exercise specific personal jurisdiction.").

89 See, for example, Omni Capital, 484 US at 101-02 (holding that jurisdiction could not be exercised over an English defendant in the absence of a jurisdictional statute despite the fact the defendant had contacts spread across the United States).

90 The ACPA was enacted as an amendment to the Federal Trademark Act of 1946 ("Lanham Act"), Pub L No 107-200, 60 Stat 441, codified at 15 USC \$1125(a)(1) (1994). For the amendment to the Lanham Act, see ACPA, S 1948, 106th Cong $\$ 3002$ (1999). Neither the ACPA nor the Lanham Act contains provisions authorizing service of process on defendants for in personam actions. The ACPA does, however, contain such a provision for in rem actions. Plaintiffs filing in rem claims may obtain service of process over defendants by sending notice of the alleged violation and intent to proceed to the registrant, and by publishing notice of the action as directed by the court. See 15 USC $\$ 1125(d)(2)(B)$. Plaintiffs may still rely on Rule 4(k)(2) when filing in personam claims because there is not a corresponding ACPA provision for service for in personam actions. 
tiffs seeking to assert in personam jurisdiction over the cybersquatter, however, may seek to do so under the "effects" doctrine if the defendant has directed harmful effects into the forum. Courts, through Rule $4(\mathrm{k})(2)$, also may exercise in personam jurisdiction over foreign cybersquatters on the basis of contacts they establish with the nation as a whole.

\section{APPLICATION OF THE ACPA}

The scope of Shaffer's holding has sparked debate. Most commentators contend that minimum contacts rules now apply uniformly to both in rem and quasi in rem actions, ${ }^{\text {,1 }}$ and most circuit courts agree with this interpretation..$^{2}$ A few commentators suggest, however, that Shaffer's mandate does not apply to in rem actions, such as those brought under the ACPA. They insist that since this type of claim was not directly at issue before the Court, Shaffer's holding is limited to quasi in rem actions.

The debate over Shaffer impacts the ability of mark owners to obtain relief when victimized by overseas cybersquatters. Most foreign cybersquatters-except those who have actively attempted to extort money from the mark owner-lack minimum contacts with any one state and thus do not appear to be subject to in personam jurisdiction. Most mark owners facing such defendants therefore seek relief through ACPA in rem claims filed in the forum in which the domain authority is located. Courts are divided, however, over whether Shaffer mandates that these plaintiffs demonstrate that the mark owners have minimum contacts with the forum.

Part A will examine the division among courts over whether minimum contacts analysis applies to ACPA in rem actions. Part B will show that attempts to limit Shaffer's holding to quasi in rem claims di-

91 See, for example, Silberman, 53 NYU L Rev at 71 (cited in note 45) (stating that Shaffer "erect[s] a new test against which all assertions of state court jurisdiction must be measured").

92 See, for example, Applewhite v Metro Aviation, Inc, 875 F2d 491, 495 (5th Cir 1989) (stating that "whether the action is instituted in personam, quasi in rem or otherwise" it must be measured under the International Shoe standard); Pittsburgh Terminal Corp v Mid Allegheny Corp, 831 F2d 522, 526 (4th Cir 1987) ("The narrow holding of [Shaffer] was a simple one: the minimum contacts rule of International Shoe would henceforth be applied to actions in rem and quasi in rem, as well as to actions in personam."); Nehemiah $v$ Athletics Congress of USA, 765 F2d 42, 47 (3d Cir 1985) (emphasizing that Shaffer "required that the minimum contacts test be used to evaluate the existence of all claims of in rem jurisdiction"); Burger King Corp v Macshara, 724 F2d 1505, 1510 (11th Cir 1984) (noting that Shaffer abandoned traditional in rem jurisdictional analysis in favor of the minimum contacts test), revd on other grounds, 471 US 462 (1985); Lindsey v Greene, 649 F2d 425, 427 (6th Cir 1981) (noting that the Supreme Court has effectively erased any distinctions between in rem and in personam jurisdiction); Lakeside Bridge \& Steel Co v Mountain State Construction Co, 597 F2d 596, 600 (7th Cir 1979) (stressing that in Shaffer, "the principles of International Shoe were held to govern assertion by a state of in rem as well as in personam jurisdiction"). 
rectly contradict language in the opinion and subsequent Supreme Court decisions, and that plaintiffs in ACPA in rem claims thus must satisfy the minimum contacts standard. Part $\mathrm{C}$ demonstrates why plaintiffs will find it difficult to prove minimum contacts if a foreign cybersquatter's only contact with the forum is the mere registration of the domain name.

\section{A. The Debate over Shaffer}

Courts are split over whether Shaffer's holding applies to in rem claims filed under the ACPA. Several courts require ACPA in rem plaintiffs to demonstrate that mark owners have minimum contacts with the forum. While only the exercise of quasi in rem jurisdiction was at issue in Shaffer, these courts stress that the logic of the Supreme Court's opinion extends further." Shaffer rejected the legal fiction that in rem proceedings affected only the disposition of property and not the interests of the property owner. ${ }^{9 s}$ Since the exercise of jurisdiction over property determines the defendant's property interest and can thus be viewed as an assertion of jurisdiction over the defendant owner, courts may exercise in rem jurisdiction only when "the Due Process Clause would have permitted in personam jurisdiction over those who have an interest in the res." ${ }^{\text {" }}$ Plaintiffs thus must show that defendants have minimum contacts with the forum. ${ }^{\text {.7 }}$ While the Supreme Court recognized that this standard is usually satisfied in in rem claims in which the property at issue is located in the forum, it expressly noted that in some cases the mere presence of the defendant's property would not establish minimum contacts.

93 See FleetBoston Financial Corp v Fleetbostonfinancial.com, 138 F Supp 2d 121, 134 (D Mass 2001) (stating that the efforts to narrow Shaffer are not consistent with the holding of the case); Porsche Cars North America, Inc v Porsch.com, 51 F Supp 2d 707, 712 (E D Va 1999) (holding that courts cannot exercise in rem jurisdiction unless the property owner is subject to in personam jurisdiction in the forum), vacd on other grounds and remd, Porsche Cars North America, Inc v Allporshe.com, 215 F3d 1320 (4th Cir 2000). Porsche predated enactment of the ACPA and the plaintiff filed its claim under the Lanham Act before it was amended to include the ACPA. While the court did not specifically address the ACPA, its interpretation of Shaffer remains applicable.

94 See FleetBoston, $138 \mathrm{~F}$ Supp 2d at 133 (noting that the effort to narrow Shaffer's holding "does not appear altogether consistent with the reasoning of the Shaffer opinion or subsequent Supreme Court precedent").

95 See, for example, Porsche, 51 F Supp $2 \mathrm{~d}$ at 712 (recognizing that "in rem proceedings ... necessarily affect the interests of persons as well").

96 Id.

97 See id.

98 See Shaffer, 433 US at $208 \mathrm{n} 25$ (noting that sometimes the presence of property in a state does not indicate an expectation to benefit from the state's protection). While these courts agree that plaintiffs must establish minimum contacts, they differ over how this standard may be satisfied. After dismissing the case on other grounds, the court in FleetBoston noted in dicta that defendants may establish minimum contacts by simply registering the domain name with a regis- 
Numerous other courts reject this broad interpretation of Shaffer and hold that minimum contacts analysis does not apply in ACPA in rem actions." These courts begin by classifying ACPA in rem claims as "true" quasi in rem actions. ${ }^{100}$ In an ACPA in rem claim, a plaintiff asserts a direct right to a domain name controlled by a registrar or registry located in the forum. These are "true" in rem actions since the claim is "directly against the property, with the narrow purpose to adjudicate the ownership of that property against the claims of all persons." ${ }^{101}$ Shaffer, however, involved a quasi in rem action since the stock certificates seized as the basis for exercising jurisdiction were unrelated to the plaintiff's claim. ${ }^{102}$ The holding that minimum contacts analysis applies to all assertions of in rem jurisdiction was, these courts argue, "non-binding dicta" in so far as it applied to "true" in rem actions not then before the court. ${ }^{103}$ The principles of territorialism permitted a court's exercise of in rem jurisdiction over property located in the forum without regard to any other constitutional requirements. $^{104}$

\section{B. Mark Owners Must Show Minimum Contacts}

While courts are correct that much of the language in Shaffer is dicta, the Shaffer opinion demonstrates that the Supreme Court in-

try located in the forum. See 138 F Supp $2 d$ at 135 . In Porsche, the court suggested that registration alone was not enough. See $51 \mathrm{~F}$ Supp $2 \mathrm{~d}$ at $712-13$. The court refused to exercise jurisdiction "merely because NSI maintains the underlying [domain name] registration certificates within this district." Id at 712.

99 See Cable News Network LP, LLLP v CNNews.com, 162 F Supp 2d 484, 491 (E D Va 2001) (siding with courts that limit Shaffer to only type II quasi in rem cases); Caesars World, Inc v Caesars-Palace.com (I), 112 F Supp 2d 502, 504 (E D Va 2000) ("[U]nder Shaffer, there must be minimum contacts to support personal jurisdiction only in those in rem proceedings where the underlying cause of action is unrelated to the property which is located in the forum state."); Heathmount AE Corp $v$ Technodome.com, 2000 US Dist LEXIS 20316, *7 (E D Va 2000) (noting that Shaffer did not purport to address purely in rem actions).

100 See, for example, Caesar (I), $112 \mathrm{~F}$ Supp 2d at 502 (finding that the domain name is the "entire subject matter" of the cause of action).

101 Caesars World, Inc v Caesars-palace com (II), 112 F Supp 2d 505, 508 (E D Va 2000).

102 See 433 US at 193.

103 See, for example, Cable Ńews Network, 162 F Supp at 491. The ACPA's structure and legislative history suggest that Congress similarly believes that Shaffer's scope is limited. A Conference Cormmittee Report accompanying the bill stresses that Shaffer only calls into question the viability of quasi in rem jurisdiction. See Intellectual Property Communications Omnibus Reform Act of 1999, HR Rep No 106-464, 106th Cong, 1st Sess 113-14 (1999). The report further contends that Shaffer reaffirms the "propriety of in rem proceedings . . . where "claims to the property itself are the source of the underlying controversy between the plaintiff and the defendant." Id. The text and structure of the ACPA confirm Congress's belief. The Act only permits plaintiffs to bring in rem actions if they are unable to show minimum contacts for the purpose of obtaining in personam jurisdiction over the defendant. See 15 USC $\$ 1125(d)(2)(A)$ (ii). This confirms that Congress believes that minimum contacts standards do not apply to the exercise of in rem jurisdiction.

104 See generally Pennoyer, 95 US at 727. 
tended to require that the minimum contacts analysis apply universally to all assertions of jurisdiction. Subsequent opinions by the Court demonstrate the validity of the broad interpretation of Shaffer's holding. The ACPA in rem provision, which bars plaintiffs from bringing in rem claims if minimum contacts exist, ${ }^{105}$ is thus likely nullified because Shaffer requires that plaintiffs establish minimum contacts in all in rem actions.

The Supreme Court in Shaffer rejected the traditional conception of in rem jurisdiction that enabled courts to assert jurisdiction over property merely because it was found in the forum. The Court ended formalist distinctions between in rem and in personam actions by emphasizing that the exercise of jurisdiction over property necessarily involves the exercise of jurisdiction over the property owner. ${ }^{106}$ Once these distinctions are abandoned, there is no support for the claim that the territorial conception of in rem jurisdiction remains intact. This category of claim is not any less an assertion of jurisdiction over a property owner. The Court, while recognizing that there were different types of in rem jurisdiction, refused to limit its analysis to quasi in rem claims. ${ }^{107}$ Instead Shaffer holds that "all assertions" of jurisdiction "must be evaluated according to the standards set forth in International Shoe and its progeny." Most circuit courts adhere to the broad interpretation of Shaffer's holding. ${ }^{109}$

The Court confirmed its broad intentions by describing how the minimum contacts standard should be applied to "true" in rem claims. In such cases, the defendant's claim to property in the forum would likely qualify as purposeful availment and thus provide the necessary contacts. "The Supreme Court qualified this statement, however, stating that "in some circumstances, presence of property in the forum State will not support [this] inference."111 The Court's suggestion that property ownership in some cases might not establish minimum contacts goes against the claim that "true" in rem assertions are per se valid." ${ }^{12}$ This suggestion leads to the conclusion that there are instances

105 See 15 USC $\$ 1125$ (d)(2).

106 See Shaffer, 433 US at 212 (announcing that it is a "fiction" to hold that "an assertion of jurisdiction over property is anything but an assertion of jurisdiction over the owner of the property").

107 See id at 207 (analyzing the impact of the minimum contacts standard on "true" in rem and type I quasi in rem proceedings).

$10 \mathrm{~s}$ Id at 212.

109 See note 92.

110 See Shaffer, 433 US at $208 \mathrm{n} 25$.

111 Id ("In some circumstances the presence of property in the forum State will not support the inference suggested in text.").

112 For a counterargument, see David F. Fanning, Note, Quasi In Rem On the Cyberseas, 76 Chi-Kent L Rev 1887, 1919 (2001) (arguing that Shaffer's language "suggests a per se rule that supports quasi in rem jurisdiction wherever there is some conceivable relation between property 
in which courts cannot exercise jurisdiction on the basis of the defendant's property within the forum state-even when that property is related to the cause of action (an assertion of in rem jurisdiction). Jurisdiction in these cases no longer depends on the location of property in the forum but instead on the amount of contacts between defendant property owners and the forum.

In subsequent decisions, the Court has reaffirmed the applicability of minimum contacts analysis to all in rem claims. In Burnham $v$ Superior Court of California, ${ }^{113}$ Justice Scalia restated Shaffer's dictate that "all assertions" of jurisdiction be judged by International Shoe: "[Shaffer] places all suits against absent nonresidents on the same constitutional footing, regardless of whether a separate Latin label is attached to one particular basis of contact." ${ }^{\text {"11 }}$ Some commentators argue that Justice Scalia left room for the traditional exercise of in rem jurisdiction, however, when he stated that "Shaffer ... stands for nothing more than the proposition that when the 'minimum contact' that is a substitute for physical presence consists of property ownership it must, like other minimum contacts, be related to the litigation." "115 This statement merely confirms, however, Shaffer's analysis that in true in rem cases property ownership will usually supply the necessary minimum contacts.

Justice Brennan, in a concurring opinion in Burnham, also affirmed International Shoe's application to "all rules of jurisdiction."116 He reasserted even more strongly Shaffer's broad application: "While our holding in Shaffer may have been limited to quasi in rem jurisdiction, our mode of analysis was not."117

Because plaintiffs filing in rem actions must demonstrate minimum contacts, the ACPA's in rem provision is nullified. Under the Act, plaintiffs may only bring in rem claims when they are unable to bring an in personam suit. ${ }^{118}$ Shaffer mandates, however, that the same minimum contacts standard applies to both in personam and in rem actions. If Shaffer is to be satisfied, there are no instances in which a plaintiff could bring an in rem claim under the ACPA. To the extent

\footnotetext{
of a certain nature and the subject matter of the cause of action").

113495 US 604 (1990).

114 Id at 621.

115 Id at 620. For the argument that this passage indicates that the traditional exercise of in rem jurisdiction is preserved, see Lee, 75 Wash L Rev at 139 (cited in note 22) ("Justice Scalia's opinion in Burnham seemed to go out of its way to leave room under Shaffer for the traditional exercise of true in rem jurisdiction.").

116495 US at 630 (Brennan concurring) (noting that "the critical insight of Shaffer is that all rules of jurisdiction, even ancient ones, must satisfy contemporary notions of due process").

117 Id. In Quill Corporation v North Dakota, 504 US 298, 307 (1992), the Court voiced its agreement with Justice Brennan in finding that Shaffer extended minimum contacts analysis "to in rem jurisdiction."

118 See 15 USC $\$ 1125$ (d)(a).
} 
that the Act's in rem provision authorizes in rem actions when minimum contacts do not exist, the provision is also unconstitutional. ${ }^{119}$ This provision should be severable, however, from the rest of the ACPA. If a statute lacks a severability or nonseverability clause to provide guidance, courts presume a statutory provision to be severable unless: (1) the remaining portion of the statute is not a fully operative law; or (2) it is evident that the legislature would not have enacted the statute without the offending provision. ${ }^{120}$ Under this standard, the in rem provision is severable. The remaining provisions of the ACPA authorizing in personam actions would continue to operate as a fully functioning law. There is also no reason to presume that Congress, which sought to provide all possible forms of relief to mark owners, ${ }^{121}$ would not wish to preserve the right of plaintiffs to file in personam claims.

\section{Mere Registration Does Not Establish Minimum Contacts}

Mark owners must seek relief through ACPA in personam claims. Plaintiffs face a difficult challenge when confronting foreign cybersquatters who merely registered domain names, and who have not yet engaged in extortion. These defendants' only contact with the United States may be the registration of the trademark-infringing domain name. Most courts hold that mere registration with a forum domain authority, however, does not establish minimum contacts. ${ }^{122}$ In America

119 For a general discussion of this issue, see Cable News Network LP, LLLP v CNNews.com, 162 F Supp 2d 484, 491 n 21 (E D Va 2001); Eugene R Quinn, Jr, The Evolution of Internet Jurisdiction: What a Long Strange Trip It Has Been, 2000 Syracuse L \& Tech J 1, 53.

120 Alaska Airlines v Brock, 480 US 678, 684 (1987) ("Unless it is evident that the Legislature would not have enacted those provisions which are within its power, independently of that which is not, the invalid part may be dropped if what is left is fully operative as a law.") (citations omitted).

121 See generally The Anticybersquatting Consumer Protection Act Report, S Rep No 106140, 106th Cong, 1st Sess 7-8, 10-11 (1991).

122 See Cable News Network LP, LLLP v CNNews.com, 162 F Supp 2d 484, 489 n 16 (E D Va 2001) (noting that "[i]t is sensibly settled that these contacts do not provide a constitutionally adequate basis for the exercise of in personam jurisdiction"); America Online, Inc v Huang, $106 \mathrm{~F}$ Supp 2d 848, 866 (E D Va 2000) (holding that entrance into domain name registration agreements with a Virginia registrar are not sufficient contacts with Virginia for purposes of exercising in personam jurisdiction); Banco Inverlat, $S A$ v Inverlat.com, 112 F Supp 2d 521, 522 n 1 (E D Va 2000 ) (holding that mere registration of a disputed domain name with NSI in Virginia is insufficient to subject a defendant to in personam jurisdiction); Heathmount AE Corp $v$ Technodome.com, $106 \mathrm{~F}$ Supp 2d 860, 866 (E D Va 2000) (emphasizing that defendants do not purposefully avail themselves of the forum through mere registration). Only a small number of courts find that registration alone satisfies minimum contacts requirements. See Caesars World, Inc $v$ Caesars-Palace.com (I), 112 F Supp 2d 502, 504 (E D Va 2000) ("To the extent that minimum contacts are required for in rem jurisdiction under Shaffer, ... the fact of domain name registration with Network Solutions, Inc., in Virginia supplies that"); Lucent Technologies v. Lucentsucks.com, 95 F Supp 2d 528, 535 n 5 (E D Va 2000) (holding that registration of a domain name with NSI in Virginia was a minimum contact sufficient to support in personam jurisdiction 
Online $v$ Huang, ${ }^{123}$ the court emphasized that a contract between the registrant and the domain authority establishes no connection between the defendant and the forum. ${ }^{124}$ Even more importantly, defendants often may not even know where the domain authority with which they are registering is located. ${ }^{125}$ The analysis of America Online and other courts can be confirmed through a close examination of Shaffer and the domain name registration process.

1. Ownership of property in the forum does not guarantee minimum contacts.

In most cases, property ownership suggests that the owner intends to benefit from the protection of the state's laws. ${ }^{126}$ The Supreme Court in Shaffer explicitly acknowledged that this might not always be the case. ${ }^{127}$ The Restatement (Second) of Conflicts provides that a state will not normally exercise in rem jurisdiction over property that has been brought into the state by way of fraud or without the owner's consent. ${ }^{123}$ In such circumstances, there is no purposeful availment. Owners do not purposefully seek to benefit from the forum since they may not even be aware that their property has passed into the state. This analysis suggests that courts may not presume that domain name registrants have minimum contacts with the forum merely because they own property (the domain name) that is "housed" in the forum state. Courts must ask whether registration of a domain name in the forum indicates purposeful availment or whether the situation of registrants is more analogous to that of the property owners discussed in Section 60 of the Restatement.

over the defendant). None of these courts devotes much analysis to the issue beyond the claim that registration puts defendants on notice that they are subject to jurisdiction in that forum. See, for example, Lucent, $95 \mathrm{~F}$ Supp 2d at $535 \mathrm{n} 5$.

123106 F Supp $2 d 848$ (E D Va 2000).

124 See id at 856 (" $[N]$ either the circumstances of the contracts' execution or negotiation, nor the relationship of the contracts to the forum state are sufficient to establish personal jurisdiction over eAsia.").

125 See id at 857 (writing that the defendant might not have known because "corporations routinely operate in many different states, yet choose one state in which to litigate claims arising from its contracts").

126 See Shaffer, 433 US at 208.

127 See id at $208 \mathrm{n} 25$ ("In some circumstances, the presence of property in the forum State will not support the inference [of purposeful availment] suggested in text."), citing Restatement (Second) of Conflicts $\$ 60$ comments c, d (1971).

128 See Restatement (Second) of Conflicts $\$ 60$ comments c, d (cited in note 127). 


\section{Registration does not satisfy the purposeful availment standard.}

Cybersquatters do not purposefully avail themselves of the benefits of state laws by the mere fact that their domain name information is stored at a registry in the forum. For example, Internet users registering domain names with Verisign are never directly informed where their domain names are "housed" or even where the corporation is located. ${ }^{12)}$ Even registrants who search the site to discover with whom they are contracting and where that party is located will most likely be led astray. The title and graphics of the website's main page indicate that it is maintained and run by Verisign. ${ }^{130}$ Registrants must independently click on the site's contact information page to discover that Verisign's headquarters is in California. ${ }^{131}$ They must also click on the privacy agreement to find that the office of NSI's general counsel is in Virginia. ${ }^{12}$ Neither page, however, indicates whether the domain name is "housed" at either of the two locations. It is difficult to see how registrants purposefully avail themselves of the protection of Virginia's or California's laws if they cannot discover where their property is stored.

This is even more evident when the defendant registers with a registrar other than Verisign. For example, if an individual registers with Alldomains.com, a California-based registrar, his sole point of contact during registration is with that company. ${ }^{133}$ His domain name will likely still be "housed," however, with Verisign since it is the exclusive registry for ".com" addresses. ${ }^{134}$ Under the ACPA, a plaintiff may bring an in rem action in the forum in which the registrar or registry is located..$^{135}$ Thus the ACPA presumes that the registrant above would have established minimum contacts with both California and

129 See Verisign Domain Name Registration Information, available online at <http://www.netsol.com> (visited May 7, 2002). Users must independently click links off of Verisign's main page in order to determine where that company and NSI are located. See Verisign Main Page, available online at <http://www.verisign.com> (visited May 7, 2002); Verisign Contact Information, available online at $<\mathrm{http}: / /$ www.verisign.com/corporate/about/contact/ $>$ (visited May 7, 2002) (indicating that Verisign's headquarters is in California); Verisign Privacy Agreement, available online at <http://www.netsol.com/en_US/legal/privacy-policy.jhtml> (visited May 7,2002) (indicating that NSI is based in Virginia).

130 Verisign Domain Name Registration Information, available online at <http:/ www.netsol.com/en_US/index.jhtml?_requestid=3863854> (visited May 7,2002).

131 See Verisign Contact Information, available online at <http://www.netsol.com/en_US/ contactus.jhtml> (visited on May 7,2002).

132 See Verisign Privacy Agreement129, available online at $<$ http://www.netsol.com/en_US/ legal/privacy-policy.jhtml> (visited May 7,2002).

133 See Alldomains.com Domain Name Registration Information, available online at $<$ http://www.alldomains.com> (visited May 7, 2002).

134 See Verisign Corporation Information, available online at <http://www.verisigngrs.com/ aboutus $/>$ (visited on May 7, 2002).

135 See 15 USC $\$ 1125$ (d)(2)(A). 
Virginia, even though the only party with which he communicated was Alldomains.com, based in California. ${ }^{136}$

The situation of domain registrants parallels that of the property owners discussed in the Restatement. ${ }^{137}$ In both cases, property enters into a state without the owners' knowledge. The owners in the Restatement are unaware where their property is located because they have been defrauded or otherwise failed to give consent to the movement of their property. A registrant who registers with a registrar, say Alldomains.com, may similarly believe that his domain name is located in one state (California) when in reality it has been transferred to a registry in another state (Virginia). The same holds true for a registrant who registers with California-based Verisign but does not specifically consent to have his property stored in a registry in Virginia. Assertion of jurisdiction merely because a forum registry maintains registration certificates of the domain name violates the owner's rights to fair play and substantial justice. ${ }^{13 s}$

3. Cybersquatters do not establish substantive connections with the forum through registration.

The act of registration is also insufficient to establish minimum contacts with the forum. Registration is accomplished through a single exchange over the Internet lasting for only a few minutes. ${ }^{139}$ A single contract between a defendant and a forum resident, however, may establish minimum contacts. ${ }^{140}$ The contract, however, must have a "substantial connection" with the forum. ${ }^{141}$ In determining whether the contract satisfies this standard, courts look to the prior negotiations and future duties of the parties to determine whether the defendant purposefully established minimum contacts with that forum. ${ }^{1.2}$

136 See Alldomains.com Contact Information, available online at <http:// www.alldomains.com/contact.html> (visited May 7,2002) (listing Concord, CA as the company's mailing address).

137 See Restatement (Second) of Conflicts, $\$ 60$ comments c, d.

138 See Porsche Cars North America, Inc v Porsch.com, 51 F Supp 2d 707, 712-13 (E D Va 1999) (holding that "by validating an in rem proceeding that would cancel or reassign certain domain names, merely because NSI maintains the underlying registration certificates within this district [and] without regard to the interests of those who registered them ... might violate due process"), vacd on other grounds and remd, 215 F3d 1320 (4th Cir 2000).

139 See Verisign Domain Name Registration Information, available online at <http:// www.netsol.com/en_US/index.jhtml> (visited May 7,2002) (displaying the interface by which users may begin to register a domain name).

140 See McGee v International Life Insurance Co, 355 US 220, 223 (1957) (finding that a single contract, entered into by mail with a forum state resident, may satisfy minimum contacts for a suit for a claim arising from the contract).

141. Id.

142 See Burger King Corp v Rudzewicz, 471 US 462,479 (1985) ("It is these factors-prior negotiations and contemplated future consequences, along with the terms of the contract and the parties' actual course of dealing - that must be evaluated in determining whether the defendant 
The contract between registrants and registrars fails this standard. The process of registration and the duties imposed by the contract do not give rise to any substantive connection between the forum and registrant. Registration is brief, performed over the Internet, and does not involve negotiation of terms. Neither registrars nor registries perform any substantial services in the forum as a result of the contract. ${ }^{13}$ The only lasting connection between the registrant and the forum is the $\$ 30$ to $\$ 35$ annual maintenance fee paid to the registry by credit card over the Internet. These payments do not create an ongoing business relationship between the registrant and registrar "any more than a magazine subscription creates an ongoing relationship between the publisher and subscriber., ${ }^{144}$

Mark owners will thus be unable to obtain relief through the ACPA's in rem provision. The difficulties facing mark owners can best be seen through the hypothetical described in the Introduction. The ACPA requires Intel to bring its in rem claim against "pentium3.com" in Virginia where Verisign, the domain name authority, is located. As dictated by Shaffer, however, Intel must establish minimum contacts between Blofeld and Virginia. Because Intel must demonstrate minimum contacts, it will be unable to bring an in rem claim under the ACPA. Finally, Intel will be unable to obtain in personam jurisdiction over Blofeld in Virginia by simply pointing to his registration with Verisign.

\section{Proposed Solution}

Because in rem claims must pass the International Shoe minimum contacts standard, plaintiffs will be unable to bring in rem actions under the ACPA. ${ }^{145}$ Mark owners will also face possible difficulty in obtaining in personam jurisdiction over foreign cybersquatters who register an infringing domain name but who do not attempt directly to extort the mark owner.

Mark owners may file in personam claims against these cyberpirates by employing the "effects" doctrine and Rule 4(k)(2). ${ }^{146}$ Part A

purposefully established minimum contacts within the forum.").

143 See America Online, 106 F Supp 2d at 855 n 21 (stating that NSI, a predecessor of Verisign, only had to maintain the defendant registrant's second level domain server information in its database).

144 Id at 857.

145 See Part II.B.

146 While no court has employed the "effects" doctrine and Rule 4(k)(2) in combination, their use together presents no theoretical problem. The "effects" doctrine demonstrates an instance in which a defendant establishes minimum contacts. See Part I.C.4. Rule 4(k)(2) permits the aggregation of such contacts to determine whether the defendant has minimum contacts with the nation as whole. See Part I.C.5. Thus, the former shows when a defendant has minimum contacts and the latter allows federal courts to exercise in personam jurisdiction over a defendant on 
demonstrates how under the "effects" doctrine, plaintiffs may demonstrate that cybersquatters establish contacts with the nation as whole when they register with a forum and when the harmful effect of that registration is felt by United States businesses. ${ }^{147}$ Part B suggests that federal courts may, under Rule 4(k)(2), use these nationwide contacts as a basis for asserting in personam jurisdiction over the defendants. ${ }^{1.8}$ Part $\mathrm{C}$ concludes by finding that this exercise of jurisdiction also satisfies traditional notions of fair play and substantial justice.

\section{A. Cybersquatters Establish Minimum Contacts by Targeting United States Businesses}

Under the effects doctrine of Calder, a defendant may establish minimum contacts if he: (1) commits intentional actions expressly aimed at the forum; and (2) those actions cause harm (a) that is felt primarily in the forum and (b) that the defendant knows will be felt there. Courts have employed this test to obtain in personam jurisdiction over cybersquatters attempting to extort money from forum state businesses. ${ }^{19}$ They should equally be able to use the doctrine to exercise jurisdiction over defendants who register domain names with the bad faith intent to attract the mark owner's customers or with the purpose of disparaging the mark. These cybersquatters intentionally target U.S. mark owners and are aware that the owners will suffer harm in the United States. ${ }^{150}$

Foreign cybersquatters satisfy the first prong of the test by expressly targeting American businesses. In Panavision, the court held that this prong of the effects test was satisfied when the defendant attempted to extort money from a California business. ${ }^{\text {isl }}$ Since the defendant targeted a business he knew to be located in the California fo-

the basis of those contacts.

147 See Part I.C.4.

148 See Part I.C.5.

149 See text accompanying notes 74-83.

150 While the "effects" doctrine has not previously been used to establish a defendant's contacts with the nation as a whole, courts have recognized the validity of asserting personal jurisdiction based on nationwide contacts. See notes 84-89. Also, when federal courts entertain federal claims, such as those actions filed under the ACPA, they look to the defendant's contacts with the United States. See United Rope Distributors Inc $v$ Seatriumph Marine Corp, 930 F2d 532, 534 (7th Cir 1991) (holding that when federal courts apply federal law, due process clause requirements are satisfied so long as the defendant possesses sufficient contacts with the United States). A court entertaining an ACPA in personam action will thus assess a cybersquatter's contacts throughout the United States. The effects doctrine may then be used to show that foreign cybersquatters establish nationwide contacts when they register protected marks and cause injury to U.S. mark owners.

151 See Panavision, 141 F3d at 1322 (holding that personal jurisdiction was properly exercised over defendant where a website was obtained by defendant "for the purpose of extorting money from Panavision"). See also text accompanying notes 74-79. 
rum, the court interpreted his actions to be aimed intentionally at the forum. ${ }^{1.2}$ In the same way, foreign cybersquatters target the nation as a whole by seeking to profit unfairly from or disparage protected marks. They are aware that marks such as "Pentium" are controlled by American businesses. They directly target American mark owners and seek to confuse American, as well as worldwide, Internet users into believing that the cybersquatter sites are affiliated with the mark owner.

The second prong of the test is first satisfied because plaintiffs suffer immediate injury from the unlawful registration and use of their marks as domain names. Registration prevents a business from using the domain name itself in order to channel consumers to its own website. ${ }^{1.35}$ Internet traffic seeking the business's site is redirected to sites established by the cybersquatter. Not only do these businesses lose contact with potential customers, but also the value of their marks is diminished. ${ }^{1.4}$ Significantly, Congress recognized this harm by creating a cause of action for the mark owner under the ACPA.

The second prong is also satisfied because foreign cybersquatters recognize that when they tarnish the good will of the mark, the harm they inflict is felt in the United States. These cyberpirates differ, however, from the defendant in Panavision who established minimum contacts with California when he attempted to extort money from a California-based company. ${ }^{155}$ Foreign cybersquatters who register infringing domain names with the intent to confuse consumers likely will not establish minimum contacts with the state in which the mark owner suffers the harm. The difference between these two is demonstrated by analysis under the second prong of the "effects" doctrine. In Panavision, the plaintiff could easily demonstrate that the cybersquatter knew that the harm would be suffered in California because the cybersquatter mailed letters demanding money to the business in California. ${ }^{155}$ The plaintiff facing a cyberpirate who does not engage in extortion, however, may find it difficult to show that the defendant was aware of the particular state in which the harm would be felt. He will find it much easier to prove that the defendant was aware more broadly that the harm would be felt in the United States.

152 See Panavision, 141 F3d at 1322.

153 See Porsche Cars North America, Inc v Porsch.com, 51 F Supp 2d 707,710 (E D Va 1999) (holding that "the mere act of registration creates an immediate injury by preventing Porsche from utilizing those domain names itself"). See generally S Rep No 106-140 at 4-5 (cited in note 1).

154 See Porsche, 51 F Supp $2 \mathrm{~d}$ at 710 (holding that harm occurs when consumers reach a "dead end" because this will cause them to assume that "the strength of Porsche's brand name is not as great as they first thought").

155 See Panavision, 141 F3d at 1322.

156 See id at 1319. 
For example, when an individual registers "delta-airlines.com," he might not be expected to know that Delta Airlines's injury would be suffered at its headquarters in Georgia. He most assuredly knows, however, that this American business would feel economic losses within the United States. Since cybersquatters are expressly aware of these harmful effects, they should "reasonably anticipate being haled into court" in this country to answer for their misconduct. ${ }^{1.5}$

Unfortunately, cybersquatters registering the protected marks of foreign companies may escape this analysis. The harm felt by a small, independent company operating solely in Europe does not establish contacts between the cybersquatter and the United States. Larger international corporations with offices and regional headquarters in the United States, however, will feel losses in this country. For example, a cybersquatter registering "toyota.com" might reasonably expect that this will cause Toyota to suffer harm in the United States. In any event, the ACPA's legislative history indicates that Congress was most concerned with protecting United States businesses and United States trademarks.

\section{B. Courts Using Rule 4(k)(2) May Aggregate a Cybersquatter's Contacts with the Nation as a Whole}

Rule 4(k)(2) is used for claims arising under federal statutes that lack service of process provisions. ${ }^{159}$ The ACPA does not contain a service provision for in personam claims. ${ }^{160}$ Plaintiffs may thus rely on Rule $4(\mathrm{k})(2)$ to obtain jurisdiction over foreign defendants. The rule permits courts to exercise in personam jurisdiction over a defendant where (1) a federal claim is asserted, (2) the defendant has contacts with the nation as a whole, and (3) the defendant is shown not to be subject to personal jurisdiction in any state. ${ }^{161}$

157 World-Wide Volkswagen Corp v Woodson, 444 US 286, 297 (1980).

158 See generally Trademark Cyberpiracy Prevention Act, HR Rep No 106-412 at 6,14 (cited in note 2) (defining cybersquatting as the registration of a domain name that "infringes upon a U.S. trademark" and also stating that the real danger presented by cybersquatters is that they "destroy the value of brand-names and trademarks of American businesses").

159 See notes 84-90 and accompanying text; Kelleher, 12 Touro L Rev at 34 (cited in note 64) (stating that Rule $4(\mathrm{k})(2)$ "is intended to plug a gap in enforcement of federal law by expanding the jurisdiction of the federal courts in federal cases involving non-resident defendants").

160 For an explanation of the service of process provisions, see text accompanying notes 8990.

161 See United States $v$ Swiss American Bank, 191 F3d 30, 38 (1st Cir 1999) (stating the conditions for an assertion of jurisdiction under Rule $4(\mathrm{k})(2)$ ). Rule $4(\mathrm{k})(2)$ also permits plaintiffs to bring their claims in any federal court. Mark owners facing foreign defendants thus will no longer have to bring suit in the forum in which the domain name authority is located to file their claims. 
The applicability of the rule to the problem created by overseas cybersquatting is clear. The ACPA is a federal statute and therefore satisfies Rule 4(k)(2)'s first requirement. ${ }^{1 / 2}$ Furthermore, cybersquatters establish nationwide contacts in the United States by inflicting financial harm on American businesses. ${ }^{1 / 3}$ Finally, foreign defendants are not subject to in personam jurisdiction in any state court. These cybersquatters have only two contacts with the United States: registration of the domain name and the harmful effect they inflict on mark owners. Neither of these contacts provides sufficient basis for the exercise of in personam jurisdiction in a state court (unless the plaintiff can show cybersquatters knew the location of the company's headquarters). The state in which the domain name authority is located cannot assert jurisdiction when the defendant's only contact with the state is the act of registration. ${ }^{164}$ As noted earlier, plaintiffs facing cybersquatters who fail to engage in extortion will likely be unable to use the "effects" doctrine to establish jurisdiction in the state in which the harm is felt. To apply the "effects" doctrine successfully in such a case, the plaintiff would have to show that the cybersquatter was expressly targeting the forum state and that he realized that mark owner would suffer harm in that state. ${ }^{165}$ Most plaintiffs will be unable to meet this difficult burden. As noted above, however, they will find it relatively easy to show that the cybersquatter was aware that the mark-owning company was based in the United States. ${ }^{166}$

\section{Exercise of Jurisdiction Is Reasonable}

Because cybersquatters purposefully direct their activities at United States residents, courts may presume that the exercise of in personam jurisdiction is reasonable. ${ }^{167}$ Federal courts have a "manifest interest" in providing residents with a convenient forum for redressing injuries inflicted by foreign actors. ${ }^{1.8}$ In Calder, the Supreme Court

162 See 15 USCS $\$ 1125$ (d).

163 See text accompanying notes $155-58$.

164 See Part III.B.

165 In the example described in Part III.A, a Georgia court would only be able to exercise jurisdiction if Delta Airlines demonstrated that the defendant registering "delta-airlines.com" expressly targeted Georgia and realized that the harm suffered by the airline would be centered in that state.

166 If the defendant is aware of the connection between the mark owner and the forum state, a plaintiff may not have to use Rule $4(\mathrm{k})(2)$. Assuming that the plaintiff could show that the defendant purposefully directed harm into the state where the plaintiff's headquarters is located, the plaintiff could bring an in personam action in that state. The court would then assert jurisdiction through the "effects" doctrine.

167 See Part III.A.

168 See generally Burger King Corp v Rudzewicz, 471 US 462 (noting the reasons a court may assert jurisdiction over an individual who "purposefully directs" his activities toward forum residents). 
stressed the inequity of requiring the victims of tortious conduct to seek redress outside the forum. ${ }^{169}$ Defendants should not be able to inflict harmful effects on forum residents and then claim that the forum's exercise of jurisdiction is unreasonable.

While there is a presumption that the assertion of jurisdiction over a foreign cybersquatter is reasonable, the Supreme Court in Asahi suggested that the issue of reasonableness must be more closely examined when foreign parties are involved. ${ }^{170}$ Asahi may clearly be distinguished, however, from actions against alien cybersquatters. Asahi involved a claim between two foreign parties that arose from an overseas transaction. ${ }^{171}$ In cases of cybersquatting, however, foreign defendants intentionally inflict injury on American mark owners in the United States. The Court surely did not intend Asahi to block United States citizens from obtaining remedies for harms suffered in this country. ${ }^{12}$

By returning to the "pentium3.com" hypothetical described earlier, one can see how mark owners facing foreign cybersquatters may successfully obtain relief through the "effects" doctrine and Rule $4(\mathrm{k})(2)$. Intel may demonstrate through the "effects" doctrine that Blofeld established nationwide contacts. Intel can easily prove that, when Blofeld registered "pentium3.com" and set up a website to attract Internet users, he knowingly targeted Intel in the United States and understood that the company would suffer harm in this country. A federal court may then employ Rule $4(\mathrm{k})(2)$ to exercise in personam jurisdiction over Blofeld. The first two requirements of the rule are satisfied since Intel is asserting a federal claim under the ACPA and Blofeld has nationwide contacts. The final requirement is also satisfied since Blofeld is not likely to be subject to jurisdiction in any one state. Blofeld's only contact in the United States, aside from the harm suffered by Intel, is his registration of the domain name with Verisign in Virginia. Blofeld also is likely unaware that the harm he inflicted on Intel may be centered in its principal place of business in California. ${ }^{12}$ Because neither California nor Virginia may assert jurisdiction on the basis of these contacts, a federal court may assert jurisdiction over

169 See Calder, 465 US at 790 (emphasizing that "[a]n individual injured in California need not go to Florida to seek redress from persons who, though remaining in Florida, knowingly cause[d] the injury in California").

170 See 480 US at 116 (finding that an assertion of personal jurisdiction over the defendant was "unreasonable," even if the defendant had minimum contacts with the forum state).

171 See id at 105-06 (noting that the parties before the court were from Taiwan and Japan).

172 See id at 114 (noting that Asahi's contacts with the forum were insufficient because the indemnification took place in Taiwan and the goods were shipped from Japan to Taiwan).

173 Of course, if Blofeld is aware that his acts will cause harm in a particular state, a court in that state may assert jurisdiction though the "effects" doctrine alone, without resort to Rule $4(\mathrm{k})(2)$. 
Blofeld through Rule 4(k)(2). ${ }^{174}$ Finally, since Blofeld intentionally inflicted harm on a United States resident, there is a strong presumption that the exercise of jurisdiction is reasonable.

\section{CONCLUSION}

Foreign cybersquatters inflict substantial economic losses on American businesses. Their substantive contacts with the United States almost always appear limited to registration of the offending domain address. Mark owners will likely be unable to obtain jurisdiction over these domain names. The Supreme Court in Shaffer mandated that minimum contacts analysis apply to all assertions of jurisdiction. This ruling renders the ACPA's in rem provision null and void. Mark owners also cannot show that cybersquatters are subject to in personam jurisdiction based solely on registration of the domain names. Registrants do not purposefully avail themselves of the benefits and protections of the forum since they are often unaware of the state in which the registry or registrar is located.

Mark owners may still seek relief through claims filed directly against alien cybersquatters. Courts may use the "effects" doctrine and Rule $4(\mathrm{k})(2)$ to exercise in personam jurisdiction over these defendants. The "effects" doctrine shows that cybersquatters establish contacts with the nation as whole by deliberately inflicting injury on mark owners in the United States. Under Rule 4(k)(2), courts may exercise jurisdiction on the basis of these nationwide contacts since plaintiffs are filing federal claims under the ACPA and the defendants are not subject to jurisdiction in any one state. 
+5x:

\%

5 